\title{
COMPETITIVE INTERACTIONS BETWEEN SPECIES OF FRESH-WATER SNAILS. I. LABORATORY. IC. COMPARATIVE SURVIVAL OF BIOMPHALARIA GLABRATA AND B. STRAMINEA KEPT OUT OF WATER
}

\section{FREDERICO SIMÓES BARBOSA, * D.P. PEREIRA DA COSTA** \& FRANCISCO ARRUDA* *}

Biomphalaria glabrata and $\mathrm{B}$. straminea were submitted to an out-door laboratory experiment for testing their comparative ability to resist desiccation. Results have shown that $\mathrm{B}$. straminea is significantly higher resistant than B. glabrata. After five months under such distressing condition the survival ratios were: B. glabrata 8.1 per cent and $\mathrm{B}$. straminea 18.4 per cent.

The effects of seasonal changes on both land and fresh-water snails are well known.

The first account of the effect of desiccation on the survival of the snail intermediate hosts of Schistosomiasis was reported by Barlow (1933) during his field studies on the "winter rotation" of the water in irrigation channels in Egypt. Further observations on the survival of the planorbids under laboratory and field conditions were made in Africa by Gordon, Davey \& Peaston (1934) and Annecke \& Pea$\operatorname{cok}(1951)$.

In the Western Hemisphere similar observations were also made (Coutinho, Gouvêa \& Lucena, 1940; Brumpt, 1941; Scott, 1942; Luttermoser, 1946; Tavares, 1947).

At present, a large amount of information has been accumulated on the influence of seasonal and climatic factors in the life-cycle of the snail host of Schistosomiasis.

Studies carried out in the Northeast since 1952 (Barbosa \& Dobbin, 1952) have shown that both $B$. glabrata and $B$. straminea under laboratory conditions are able to live several months out of water and that, in the field, the snails were able to survive the dry season in sufficient number to repopulate the area when the water returned. These studies are summarized in a paper published in 1962 (Barbosa, 1962).

Oliver \& Barbosa (1955) made extensive field studies on the natural history of $B$. straminea living under two different conditions: in temporary pools and in permanent bodies of water. These snails were able to survive the long dry season in temporary pools. They observed that: "It is probable that $A$. glabratus is somewhat less resistant to drying than is T. centimetralis though this was not tested adequately".

In fact, the above empirical observation was never submitted to any experimental test.

\section{METHODS}

For the current experiment a cement tank, measuring $2.00 \mathrm{~m}$ long $\times 0,64$ wide built outside the main building was used. The open surface of the tank was screened to avoid penetration of predators. A roof was placed over the tank in such a way that a space was left between the cover and the border. This was needed to allow ventilation and at the same time avoid excessive temperatures and occasional rains.

The tank was filled with a layer of $30 \mathrm{~cm}$ of mud taken from the bottom of a stream in the county of Olinda, state of Pernambuco. Water was added to cover the mud layer leaving a $4 \mathrm{~cm}$ water free layer.

In the experiment, 320 full grow specimens of each Biomphalaria species, $B$. glabrata and $B$. straminea, collected in the county of Olinda, were used. Together with the snails some aquatic plants (Elodea sp.) were introduced. Fresh lettuce was the only food given to the snails.

The temperature of the mud surface was taken daily at 2:00 p.m. During the experiment the average temperature was $27.6^{\circ} \mathrm{C}($ S.D. $=1.3)$.

The experiment began during the dry season. Snails were introduced in the tank on November 5 , 1982. By January 18,1983 the water has completely receded although the mud was still humid.

On this date the mud surface was divided into ten rectangles measuring $12.8 \mathrm{~cm}^{2}$. At each following month two rectangles were sistematically removed according to the diagram below and their contents placed in a large pan full of water.

\footnotetext{
This work was supported by the "Financiadora de Projetos de Pesquisas" - FINEP, the "Superintendência de Desenvolvimento do Nordeste" .. SUDENE, and the "Conselho Nacional de Desenvolvimento Científico e Tecnológico" CNPq.

* Escola Nacional de Saúde Pública - FIOCRUZ, Caixa Postal 926, 20000 Rio de Janeiro, RJ, Brazil.

* Centro de Pesquisas Aggeu Magalhães - FlOCRUZ, Recife, PE, Brazil.
}

Received for publication August 28th and accepted December 14 th, 1984. 


\begin{tabular}{ccccc}
1 & 3 & 5 & 4 & 2 \\
\hline 2 & 4 & 5 & 3 & 1
\end{tabular}

The following day all the snail specimens that could be seen were transferred to small laboratory aquaria where they were allowed to stay for 24 hours for identification and determination of the live specimens. All the content of the pan was then passed through a screen to capture any snail specimen that might have escaped the first collecting procedure.

\section{RESULTS}

Table I shows the results of the comparative study on the resistance to desiccation between $B$. glabrata and $B$. straminea. The higher capability of $B$. straminea to resist drying was proved under the conditions used in the current experiment.

\section{TABLE I}

Comparative survival between $B$. glabrata and $B$. straminea kept out of water - Recife, 1983

\begin{tabular}{l|rr|c|r|r|r}
\hline \multirow{2}{*}{$\begin{array}{l}\text { Date } \\
1983\end{array}$} & \multicolumn{3}{|c|}{ B. glabrato } & \multicolumn{3}{c}{ B. straminea } \\
\cline { 2 - 8 } & Alive & Dead & \% Alive & Alive & Dead & \% Alive \\
\hline $2 / 18$ & 20 & 66 & 23.5 & 19 & 8 & 70.4 \\
$2 / 19$ & 0 & 19 & 0 & 14 & 10 & 58.3 \\
$4 / 22$ & 3 & 43 & 6.5 & 8 & 19 & 29.6 \\
$5 / 20$ & 3 & 24 & 11.1 & 15 & 30 & 33.3 \\
$6 / 24$ & 0 & 32 & 0 & 3 & 25 & 10.7 \\
\hline Total & 26 & 184 & 14.1 & 59 & 92 & 64.1 \\
\hline
\end{tabular}

The total survival figures for each species at the end of the experiment, admitting that the missing snails specimens, i.e. the difference between the original number (320) and the recovered numbers ( 210 for B. glabrata and 151 for $B$. straminea), died and desintegrated during the desiccation period, was as follows: $B$. glabrata $8.1 \%$ and $B$. straminea $18.4 \%$. The difference between the rates (10.3), is greater than twice the standard error of the difference $(2 \times 2.7=5.4): \mathrm{p}<0.001$.

These clear-cut results discard any other statistical analysis that could have been done on the data.

\section{COMMENTS AND CONCLUSIONS}

The results reported in this paper are consistent with former empirical observation suggesting that B. straminea is more resistant to desiccation than B. glabrata (Olivier \& Barbosa, 1955) despite the relative artificiality of the current out-door laboratory experiment.

The possibility that resistance to drought allied to other biological factors may favor $B$. straminea against $B$. glabrata during the process of competition in areas submitted to natural cyclic dry seasons, has been suggested (Hubendick, 1958; Richards, 1970; Barbosa, 1973).

Water temperatures in the natural breeding places in areas subjected to desiccation in northeast Brazil are much higher than those observed in the current experiment. Under natural conditions when a small collection of water is almost completely dried, the remaining layer of water may attain lethal temperatures $(400-42 \circ \mathrm{C})$ for the snails. In this case the snails penetrate the superficial layer of the soft soil, trying to escape from this distressing condition (unpublished data).

The upper limit of favorable temperature for the Pernambuco strain of $B$. glabrata is $32{ }^{\circ} \mathrm{C}$. These snails are killed after two hours exposure to a temperature of $42^{\circ} \mathrm{C}$. The optimum temperature is $25-28^{\circ} \mathrm{C}$ (WHO, 1957; Barbosa \& Olivier, 1958; Barbosa, 1962). investigated.

There are no data on the effect of temperature on $B$. straminea. This subject should be further

It is believed that in spite of arguments against the artificiality of laboratory experiments, there is enough evidence to admit that desiccation may play an important role on the dynamics of the population interaction B. glabrata X B. straminea. 


\section{RESUMO}

Biomphalaria glabrata e $B$. straminea foram submetidas a um experimento para verificar a resistência comparativa de ambas as espécies à dessecação. $O$ estudo foi conduzido em condições de laboratório em um tanque de cimento coberto, colocado fora do prédio. Os resultados mostraram que $B$. straminea é significantemente mais resistente à dessecação que $B$. glabrata. Ao final da experiência, sob as condições acima, a sobrevida foi a seguinte: $8,1 \%$ para $B$. glabrata e $18.4 \%$ para $B$. straminea.

\section{ACKNOWLEDGEMENT}

To Mr. B. José Tabosa and Miss L. Helena C.P. da Costa for technical assistance.

\section{REFERENCES}

ANNECKE, S. \& PEACOCK, P.N.B., 1951. Bilharziasis in the Transvaal. South. Af. Med. J., 25:689-692+676-680.

BARBOSA, F.S., 1962. Aspects of the ecology of the intermediate hosts of Schistosoma mansoni interfering with the transmission of bilharziasis in north-eastern Brazil. Ciba Foundation Symposium on Bilharziasis, pp. 23-25, Cairo, Egypt.

BARBOSA, F.S., 1973. Possible competitive displacement and evidence of hybridization between two Brazilian species of planorbid snails. Malacologia, $14: 401-408$.

BARBOSA, F.S. \& DOBBIN, J.E., 1952. Effects of the dry season on Australorbis glabratus. Publ. Av. Inst. Aggeu Maga. lhäes, $I: 145-147$.

BARBOSA, F.S. \& OLIVIER, L., 1958. Studies on the snail vectors of Bilharziasis mansoni in north-eastern Brazil. Bull. World Health Org., $18: 895-908$.

BARLOW, C.H., 1933. The effect of the "winter rotation" of water upon snails involved in the spread of schistosomiasis in Egypt. Am. J. Hyg., $17: 724-742$.

BRUMPT, E., 1941. Observations biologiques diverses concernant Planorbis (Australorbis) glabratus, hôte intermédiaire de Schistosoma mansoni. Ann. Parasit., 18 :9-45.

COUTINHO, B.; GOUVẼA, A. \& LUCENA, D., 1940. Investigaçōes em torno da epidemiologia da esquistossomose mansônica em Pontesin ha e Victoria, Estado de Pernambuco, Brasil, Mem. Inst. Oswaldo Cruz, $35: 207-230$.

GORDON, R.M.; DAVEY, T.H. \& PEASTON, H., 1934. The transmission of human bilharziasis in Sierra Leone, with an account of the life-cycle of the schistosomes concerned, $S$. mansoni and $S$. haematobium. Ann. Trop. Med. Parasit., $28: 323-419$.

HUBENDICK, B., 1958. A possible method of schistosome-vector control by competition between resistant and susceptible strains, Bull. Wld. Health Org., $18: 1113-1116$.

LUTTERMOSER, G.W., 1946. La campaña antibilharziana en Venezuela. XII Cong. Sanitaria Panamericana. Caracas.

OLIVIER, L. \& BARBOSA, F.S., 1955. Seasonal studies on Tropicorbis centimetralis in Northeastern Brazil. Publ. Av. Inst. Aggeu Magalhäes, $4: 105-115$.

RICHARDS, C.S., 1970. Genetics of a molluscan vector of schistosomiasis. Nature, $227: 806-810$.

SCOTT, J.A., 1942. La epidemiologia de la Schistosomiasis en Venezuela. Caracas.

TAVARES DA SILVA, L., 1947. Notas sobre a biologia dos moluscos hospedeiros de Schistosoma mansoni. An. Soc. Med. Pernambuco, $1: 66-79$.

WHO, 1957. Study Group on the Ecology of Intermediate Snail Hosts of Bitharziasis. Technical Report Series no. 120, Geneva. 